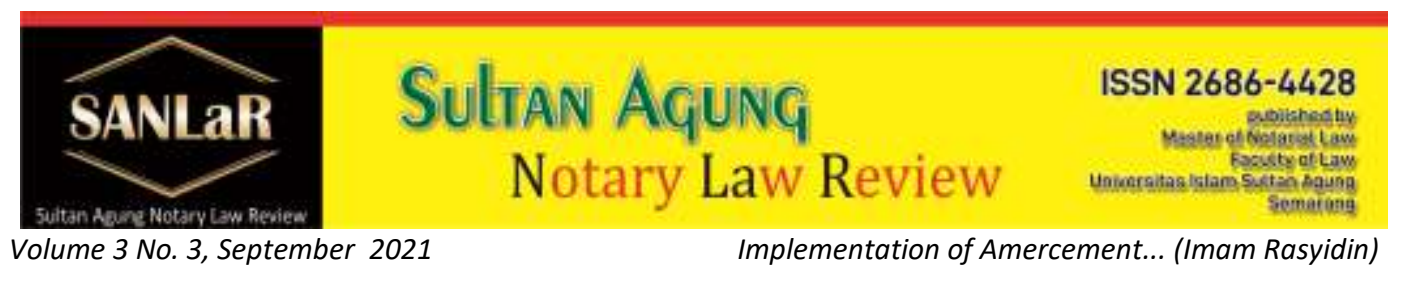

\title{
Implementation of Amercement in the Financing Contract in Islamic Banking based on Justice \& Benefits Principles
}

\author{
Imam Rasyidin*) \\ ${ }^{*}$ Faculty of Law, Universitas Islam Sultan Agung (UNISSULA) Semarang, E-mail: \\ imamrasyidin80@gmail.com
}

\begin{abstract}
Absract. In Islamic banks, the success or failure of debtors in paying their obligations to Islamic banks has a direct effect on wealth creation for depositors and owners, even for bank employees. The more successful debtors are in paying their obligations and/or providing income to the bank, the higher it will create wealth for depositors and other stake holders. However, the interests of debtors who have a vital role are still not fully accommodated in the agreement set forth in the Islamic bank financing contract. This is because the articles of financing contracts still contain clauses that are burdensome to debtors, namely amercement clause imposed on debtors when they are late in fulfilling their obligations to Islamic banks. The purpose of this study is to describe (1) the application of amercements in financing contracts in Islamic banking (2) the implications of applying amercements in Islamic banking financing contracts to the principles of justice and expediency (3) example of deed of financing in Islamic banking. This study uses sociological juridical methods to find out the exposure or explain legal phenomena as law in action, described as empirical social phenomena at PT. Bank Syariah Indonesia Cirebon Area, whether the implementation of amercements in the financing agreement has there been a match between the applicable regulations and the social reality. The results of this study conclude as follows: Based on the opinion of the majority of scholars', amercements for lateness, negligence and breaking promises are not allowed by syara', when the original obligation is in the form of debts or even payments, because these amercements can be categorized as usury and the law becomes law usury so that it is forbidden by sharia.
\end{abstract}

Keywords: Amercements; Justice; Benefit; Islamic; Bank.

\section{Introduction}

Sharia is aimed at creating or developing human problems or welfare (maqashid al-syari'ah), so Islamic banks must aim at the welfare of mankind. There are four stakeholder groups closest to an Islamic bank, namely owners (shareholders), directors and employees, customers using funds (debtors), and customers supplying funds (depositors). The four stakeholder groups must obtain a fair 
increase in welfare from Islamic banks. The measure of increasing welfare for each stakeholder is reflected in the return on equity (ROE), remuneration of employees and directors, business development of debtors, and return on investment (ROI) of depositors. ${ }^{1}$ In relation to the creation of this welfare, there are special characteristics for Islamic banks that are different from those of conventional banks. Namely, Islamic banks are institutions that facilitate the creation of direct wealth-creation between stakeholders. In the banking business, wealth creation begins with debtors, then flows to other stakeholders.

In Islamic banks, the success or failure of debtors in paying their obligations to Islamic banks has a direct effect on wealth creation for depositors and owners, even for bank employees. The more successful debtors are in paying their obligations and/or providing income to the bank, the higher it will create prosperity for depositors, and other stakeholders, and vice versa. This happens because the returns given by Islamic banks to their depositors are generally determined based on the principle of profit sharing (revenue sharing). In other words, the income received by the bank is directly distributed to depositors and owners of Islamic banks. The greater the Islamic bank earns income from the payment of obligations of its debtors,

Default of payment (failure to pay) debtors/customers is caused by the irresponsible attitude of customers to pay their installments on time, besides that there are also a few customers who actually face money problems and fail to pay their installments on time. ${ }^{2}$

The application of the amercements contained in the Fatwa of the National Sharia Council if observed carefully is not an easy thing, apart from previously agreed upon, Islamic banks must have clear and firm rules or limits for customers who are able but do not want to pay, with customers who are unable but have willingness to pay. Amercements or sanctions are imposed, only on customers who are able to pay but do not have the will to pay, so that the purpose of this amercement or sanction is to educate customers' discipline in carrying out their obligations. Meanwhile, customers who are unable to afford due to force majeure should not be subject to amercements or sanctions, even Islamic banks should provide concessions to customers until they are able to perform or fulfill their obligations. ${ }^{3}$ Force majeure which means "greater power" is an event that occurs beyond human ability and cannot be avoided so that an activity cannot be carried out or cannot be carried out properly.

${ }^{1}$ Yuslam Fauzi, Memaknai Kerja, (Jakarta: Mizan, 2012), p. 156

${ }^{2}$ Nor Azzah Kamri Fadillah Mansor. Aplikasi Konsep al-Murâbahah dalam Penawaran Instrumen di Institusi Perbankan Islam di Malaysia. API UM. Kuala Lumpur, hal. 138 lihat juga Nur Kholis. Urgensi ljtihad Akademik dalam Menjawab Problematika Muamalah Kontemporer, Al-Mawarid Ed. XIV. (2005), p. 191

${ }^{3}$ Wiroso, Jual Beli Murabahah, (Yogyakarta:UII Press, 2005), p. 135 
Islamic banks apply amercements to each of their customers who are late or do not pay installments to the bank on the due date. The amercements imposed are valid 1 day after the due date. In the sense that when the customer is 1 day late, either because the customer intentionally neglects his obligations or the customer is in a state of being unable/unable to pay the installments in that month, the bank will impose a penalty in the form of a amercement. The amount of the amercement set by the Islamic bank is 0.00069 of the total monthly installments. The amount of this amercement is fixed and does not change. The amercement of 0.00069 is multiplied by the day the customer was late. When a customer is late in paying an installment for 10 days, the amount of the monthly installment is multiplied by the amount of the amercement and multiplied by the 10 day delay. ${ }^{4}$

The application of amercements in Islamic Banks is imposed on every customer who is late or does not pay installments on the due date regardless of the background or cause of the delay. Whereas Islam really teaches its people to tolerate each other and provide space for people who are experiencing difficulties.

\section{Research Methods}

The research method is a process, principles and procedures for solving problems encountered in conducting research, which is an attempt to find, develop and test the truth of knowledge, which is carried out using scientific methods. ${ }^{5}$

\subsection{Research Approach}

Legal research as a scientific activity must always be related to the meaning that can be given to law, which is related to the method of approach used. According to Soerjono Soekanto and Purnadi Purbacaraka, these include: ${ }^{6}$

a. law in the sense of science (knowledge);

b. $\quad$ law in the sense of discipline or system of teaching about reality;

c. law in the sense of rules and norms;

d. law in the sense of legal order or written positive law;

e. law in the sense of an official's decision;

$f$ law in the sense of officers;

\footnotetext{
${ }^{4}$ Interview with Bank Syariah Indonesia employee Area Consumer Financing Manager (ACFM) Lia Ikhwatun Khasanah on Monday, March 29, 2021 at Bank Syarah Indonesia (BSI) Cirebon Area 5Sutrisno Hadi, Metodologi Research", Jilid I, (Yogyakarta : ANDI, 2000), p. 4 ${ }^{6}$ Soerjono Soekanto \& Purnadi Purbacaraka, Perihal Penelitian Hukum, Alumni, Bandung, 1979, p. 65.
} 

g. law in the sense of a governmental process;
h. law in the sense of regular and steady behavior;
i. law in the sense of the fabric of values.

The approach method used in this research is a sociological juridical approach. In a sociological juridical approach, law as law in action is described as an empirical social phenomenon. Thus the law is not only given as a fabric of values, official decisions, rules and norms, written positive law, but can also be given meaning as a teaching system about reality, regular and steady behavior, or law in the sense of an officer. With this approach, it is hoped that if the implementation of amercements in financing contracts in Islamic banking, there is a match between the applicable regulations and the social reality. Or in other words, the compatibility between law in books and law in action or compatibility between das sollen and das sein.

\subsection{Research Specification}

The specifications used in this research are descriptive analytical, which is intended to provide data as accurately as possible about a situation, ${ }^{7}$ by explaining, describing or disclosing laws and regulations related to applicable legal theories and the implementation of positive law, ${ }^{8}$ especially those related to the implications of the application of amercements in sharia banking financing contracts to the sense of justice and benefit for the parties (customers and sharia banks), which are then discussed or analyzed according to science and theories or the opinion of the researchers themselves and finally concludes. ${ }^{9}$

\subsection{Data Sources and Types Study}

Sources and Types of Data required in the preparation of this study consists of:

\section{a. Primary Data Source}

Primary data sources are data obtained directly from the source, observed, will be researched and recorded for the first time, ${ }^{10}$ obtained and collected directly from respondents in the form of information or facts. ${ }^{11}$ Data directly from respondents, namely interviews with officials of the Cirebon Area Islamic Bank and Cirebon District Notaries.

b. Secondary Data Source

\footnotetext{
${ }^{7}$ Soerjono Soekanto, op. cit, p. 10

${ }^{8}$ Margono, Metodologi Penelitian Pendidikan, (Jakarta : Rineka Cipta, 2003), p. 37

${ }^{9}$ Bambang Sunggono, Metodologi Penelitian Hukum, (Jakarta : PT. Raja Grafindo Persada, 2003), p. 43

${ }^{10}$ Marzuki, Metodologi Riset, (Yogyakarta : BPFE UII, 2003), p. 55

${ }^{11}$ Soerjono Soekanto, loc. cit, p. 1027
} 
Secondary data sources are data sources used to support basic data, ${ }^{12}$ obtained through literature study, which relates to the problem to be studied. Secondary data in this writing, include:

1) Primary Legal Material

Primary legal materials are in the form of binding basic regulations because they are issued by the government, ${ }^{13}$ whose contents discuss primary legal materials. The legal material consists of positive legal rules that are sorted by hierarchy, starting from the 1945 Constitution to other regulations under it, which include the Civil Code, the Criminal Code and the Sharia Banking Act No. 21 of 2008.

2) Secondary Legal Material

In the form of all publications about law ${ }^{14}$ and materials that are closely related to primary legal materials and can help analyze primary legal materials by: ${ }^{15}$

a) Literature review

b) Literature study in writing this thesis is done by studying library materials related to the object of research including internet media which is one source of information that can be used by researchers because it is a complete and complex source of information.

c) Scientific Discovery Results

d) In the form of writings by legal experts and other relevant documents, the material of which can be used as a reference for writing this thesis.

3) Tertiary Law Material

Tertiary legal materials in the form of legal dictionaries and encyclopedias or other books that support primary legal materials and secondary legal materials.

\subsection{Data Collection Techniques}

Data collection techniques in the preparation of this thesis is done by:

\section{a. Field Study}

Field studies were conducted to obtain primary data, by going directly into the field by conducting interviews with respondents in a structured manner. Interview is one method of collecting data by way of communication, namely contact or personal relationship between data collectors (interviewers) and data sources (respondents).

\section{b. Literature Study}

\footnotetext{
${ }^{12}$ P. Joko Subagyo, Metode Penelitian dalam Teori \& Praktek, (Jakarta : PT. Rineka Cipta, 1997, p. 89

${ }^{13}$ Burhan Ashshofa, Metodologi Penelitian Hukum, Print. Ketiga, (Jakarta : PT. Rineka Cipta, 2001), p. 103

${ }^{14}$ Peter Mahmud Marzuki, Penelitian Hukum, (Jakarta : Predana, 2000), p. 41

${ }^{15}$ Soemitro, op. cit., p. 53
} 
This is done by reading, recording and quoting information from secondary data, in order to explore theories that have developed in the sciences concerned and to make interpretations ${ }^{16}$ and research documents that are closely related to the research problem.

\subsection{Data analysis technique}

The data from this study were analyzed descriptively qualitatively, namely by describing all the findings of primary data and secondary data. The results of the analysis are used as material to formulate conclusions in order to answer the problems studied and to formulate suggestions for the parties related to this research.

\section{Results and Discussion}

\subsection{Overview of Indonesian Islamic Bank (BSI) Cirebon Area \\ a. History of Indonesian Islamic Bank (BSI) Cirebon Area}

Indonesia, as the country with the largest Muslim population in the world, has the potential to be at the forefront of the Islamic finance industry. Increased public awareness of halal matter and strong stakeholder support are important factors in the development of the halal industry ecosystem in Indonesia. This includes Islamic banks.

Islamic banks play an important role as a facilitator in all economic activities in the halal industry ecosystem. The existence of the Islamic banking industry in Indonesia itself has experienced a significant increase and development in the past three decades. Product innovation, service improvement, and network development show a positive trend from year to year. In fact, the spirit to accelerate is also reflected in the number of Islamic banks that take corporate actions. There is no exception for Sharia Banks owned by State-Owned Banks, namely Mandiri Syariah Bank, BNI Syariah, and BRI Syariah.

On February 1, 2021, which coincided with 19 Jumadil Akhir $1442 \mathrm{H}$, it marked the history of the merging of Bank Syariah Mandiri, BNI Syariah, and BRI Syariah into one entity, namely Bank Syariah Indonesia (BSI). This merger will unite the advantages of the three Islamic banks so as to provide a more complete service, wider reach, and have a better capital capacity. Supported by synergies with parent companies (Mandiri, BNI, BRI) and the government's commitment through the Ministry of SOEs, Bank Syariah Indonesia is encouraged to be able to compete at the global level.

\footnotetext{
${ }^{16}$ Mohal Nazir, Metode Penelitian, (Jakarta : Ghalia Indonesia, 1998), p. 111
} 
The merger of the three Sharia Banks is an effort to create a Sharia Bank that is the pride of the people, which is expected to become a new energy for national economic development and contribute to the welfare of the wider community. The existence of Bank Syariah Indonesia is also a reflection of the face of Islamic banking in Indonesia which is modern, universal, and provides goodness for all nature (Rahmatan Lil 'Aalamiin). ${ }^{17}$

Bank Syariah Indonesia (BSI) was present in the city of Cirebon on November 1, 2000, at that time BSI was still a Branch Office of Bank Syariah Mandiri (BSM) whose office was located at Jalan Siliwangi No. 102 Cirebon City (currently the BSI Siliwangi Sub-Branch Office). At that time BSM was led by Mr. Asep Mulyadi as the first Branch Head with 28 employees. Bank Syariah Indonesia (BSI) Cirebon Area, which currently has an office on Jalan Dr. Ciptomangunkusumo No. 89 Cirebon City, is here to facilitate the economic growth of the people of Cirebon City, Cirebon Regency, Kuningan Regency, Majalengka Regency, Indramayu Regency, Ciamis City and Regency, Tasikmalaya City and Regency, Banjar City, and Pangandaran Regency.

Bank Syariah Indonesia (BSI) Cirebon Area has 6 branch offices, 24 sub-branches and 2 cash offices spread over 8 regencies/cities. Bank Syariah Indonesia (BSI) Cirebon Area in 2021 led by Mrs. Siti Syafriyah as Area Manager with a total of 148 employees.

BSI Area Cirebon is one of the banks that carry out business activities based on sharia principles, which in its activities is to collect funds from the public in the form of deposits in the form of time deposits, savings and other equivalent forms. In addition to collecting funds from the public, BSI Cirebon Area in its business activities also provides financing such as mudharabah (profit sharing) financing, murabahah financing (sales and purchases), multi-service ijarah (lease) and activities that are commonly carried out by BSI Cirebon Area in accordance with the provisions of the Service Authority. Finance and as long as it is approved by the National Sharia Board.

b. Vision and Mission of Bank Syariah Indonesia (BSI)

1) Vision "Top 10 Global Islamic Banks"

2) Mission

a) Providing access to Islamic financial solutions in Indonesia Serve $>20$ million customers and become the top 5 bank based on assets $(500+T)$ and book value of $50 \mathrm{~T}$ in 2025

b) To become a big bank that provides the best value for shareholders Top 5 most profitable banks in Indonesia (ROE 18\%) and strong valuation (PB>2)

${ }^{17}$ https://www.ir-bankbsi.com/corporate history.html, accessed on August 6, 2021 at 21.30 
c) To be the company of choice and the pride of Indonesia's best talents A company with strong values that empowers the community and is committed to employee development with a performance-based culture

3) Share Value Indonesian Islamic Bank (BSI)

Shared ValuesBank Syariah Indonesia is abbreviated as "AKHLAK". Amanah, namely holding fast to the trust given. Competent, namely continuing to learn and develop capabilities. Harmonious, namely caring for each other and respecting differences. Loyal, which is dedicated and prioritizing the interests of the nation and state, Adaptive, which means continuing to innovate and enthusiastic in moving or facing change, and Collaborative, namely building synergistic cooperation.

\section{Position Case}

One of the factors that determine the performance of Islamic banks is the success or failure of debtors in paying their obligations to Islamic banks. The more successful debtors are in paying their obligations and/or providing income to the bank, the higher the wealth creation for depositors and other stakeholders, and vice versa. This happens because the returns given by Islamic banks to their depositors are generally determined based on the principle of profit sharing (revenue sharing). In other words, the income received by the bank is directly distributed to depositors and owners of Islamic banks. The greater the Islamic bank earns income from the payment of obligations of its debtors,

The implication is for a debtor, if he works well in managing the funds obtained from Islamic banks so that he can pay his obligations well to Islamic banks, then he will directly improve the welfare of Islamic bank depositors. On the other hand, if he is not serious, especially if he deliberately cheats on Islamic banks, so that he does not fulfill his obligations to the bank properly, then he is not only detrimental to Islamic banks, but also harms all depositors, owners and employees of Islamic banks. Therefore, the role of debtors is very vital for the realization of welfare for Islamic bank depositors and all sharia bank stakeholders. However, the interests of debtors who have a vital role are still not fully accommodated in the agreement set forth in the financing agreement of Islamic banks. This is because the articles of financing contracts still contain clauses that are burdensome to debtors, namely amercement clause imposed on debtors when they are late in fulfilling their obligations to Islamic banks. This amercement is calculated on a daily basis with a certain percentage until the debtors' obligations to Islamic banks are fulfilled. 
The case that occurred in one of the Sharia Bank Branches in Cirebon, where when the financing contract was about to take place, the Notary ${ }^{18}$ first read out the contents of the articles in the Murabahah Financing Agreement. When submitted regarding the amercement clause that will be imposed on the customer if the customer is late in paying the installments past the specified date, the customer ${ }^{19}$ will be subject to a daily late penalty of $0.00069 \times$ financing installments. The customer at that time objected to the clause and asked the Notary with the approval of the bank to replace the amercement clause with another clause that was more equitable for the customer. This is proposed with the consideration that when a customer submits a financing application, it is not at all intended from the outset that the customer will be late in fulfilling his obligations. Even if it is possible after receiving an injection of capital from a sharia bank, then the customer's business develops rapidly so that the profits obtained have exceeded the capital provided by the customer's bank, intending to pay off all his obligations to the bank even though it has not yet reached the maturity date. However, when after receiving an injection of capital from a sharia bank, the customer's business experienced a setback due to business risk factors so that the customer's repayment capacity decreased, the customer's burden was added to the amercement that was imposed every day the installment was delayed.

The application of amercements in Islamic Banks is imposed on every customer who is late or does not pay installments on the due date regardless of the background or cause of the delay. This is because the system cannot sort out or separate customers who may be subject to amercements from customers who cannot be amercementd. If the bank examines the customers one by one, it will not be able to run optimally, given the large number of financing customers at the bank. Therefore, amercements at Bank Syariah Indonesia (BSI) Cirebon Area are imposed evenly. ${ }^{20}$ Even though Allah SWT has ordered humans to give space to someone who is experiencing difficulties, and it is not permissible to increase their burden by asking them to pay some money due to their inability to pay, this

\footnotetext{
${ }^{18}$ A Chuasanga, Ong Argo Victoria. (2019). Legal Principles Under Criminal Law in Indonesia \& Thailand, Jurnal Daulat Hukum, Vol 2, $\quad$ No $1 \quad$ (2019) http://jurnal.unissula.ac.id/index.php/RH/article/view/4218 see Deen, Thaufiq., Ong Argo Victoria \& Sumain. (2018). Public Notary Services In Malaysia. JURNAL AKTA: Vol. 5, No. 4, 1017-1026. Retrieved from http://jurnal.unissula.ac.id/index.php/akta/article/view/4135

${ }^{19}$ Ong Argo Victoria, Ade Riusma Ariyana, Devina Arifani. (2020). Code of Ethics and Position of Notary in Indonesia. Sultan Agung Notary Law Review 2 (4), 397-407, http://lppmunissula.com/jurnal.unissula.ac.id/index.php/SANLaR/article/view/13536 see Yaya Kareng, Ong Argo Victoria, R. Juli Moertiyono. (2019). How Notary's Service in Thailand. Sultan Agung $\begin{array}{lllll}\text { Notary Law } & \text { Review, } & 1 & \text { 46-56, }\end{array}$ http://jurnal.unissula.ac.id/index.php/SANLaR/article/view/4435

20 Interview with Bank Syariah Indonesia employee Area Consumer Financing Manager (ACFM) Lia Ikhwatun Khasanah on Monday, March 29, 2021 at Bank Syarah Indonesia (BSI) Cirebon Area
} 
will even burden the person. Islam really teaches its people to tolerate each other and provide space for people who are experiencing difficulties.

Based on the description above, the author considers it necessary to analyze more deeply regarding the application of amercements in financing contracts in Islamic banking whether it has fulfilled the principle of justice between debtors/customers and Islamic banks, as part of an effort to make society (human) prosperous.

\subsection{Case Analysis, with Theory Used}

a. Application of Amercements in Financing Contracts at Islamic Banks Based on an Islamic Perspective

Islam teaches that muamalah must be based on justice and equality and not harm each other. The element of justice and equal can be exemplified in responding to an impact of negligence and loss in a transaction, by making an agreement that is contained in a contract in the form of clauses, where so that no one party is harmed, then the contracting party makes an agreement clause to impose a amercement on one of the parties who cannot carry out the agreement in the contract or are late in fulfilling their obligations. Then the party who violates the agreement must pay a amercement as stated in the clause of the contract for the loss he has received.

Implementation of financing contracts from Islamic financial institutions, whether based on sale and purchase contracts or other contracts, there are times when customers do not fulfill their payment obligations. The customers who do not pay consist of customers who are able to pay but delay payments and customers who are not/not able to pay due to force majeure.

In this regard, the hadith of the Prophet narrated by Nasa'i from Shuraid bin Suwaid, Abu Dawud from Shuraid bin Suwaid, Ibn Majah from Shuraid bin Suwaid, and Ahmad from Shuraid bin Suwaid reads: ${ }^{21}$

Procrastination (payments) made by people is able to justify self-esteem and give sanctions to them.

\footnotetext{
${ }^{21}$ Part Remembering the number 4 Fatwa of the National Syari'ah Council of the Indonesian Ulema Council Number 17/DSN-MUI/IX/2000 concerning Sanctions on Able Customers who Delay Payments(DSN-MUI Fatwa 17/2000), in Dr. Indira Retno Aryatie, SH, MH,https://www. Hukumonline.com/klinik/detail/ulasan/lt60b7266a560b9/bisa-bank-syariah-mengenakan-dendakarena-nasabah-telat-pay, accessed June 21, 2021 at 09.20 WIB.
} 
Based on this hadith, Islamic financial institutions are allowed to impose amercements on their customers who do not fulfill their payment obligations with a certain nominal amount that was agreed upon at the time the contract was made and signed. ${ }^{22}$ Because, if a debtor is able but delays payment, then the debtor has wronged the creditor. Therefore, amercements are used to provide discipline so that customers carry out their obligations.

The author wants to describe in this study how figh views on the clause of amercements (syartul jaza'i), because basically the law of origin of muamalah is permissible except for those that are contrary to Islamic law, in accordance with the applicable fiqh rules, namely:

Basically, all forms of muamalah can be done unless there is evidence that forbids it.

Basically, for worldly affairs, Allah SWT gives it completely to His servants or humans, but of course it is not completely handed over without any limitations that allow them to do arbitrarily.

This amercement clause (syartul jaza'i) is one of the new models in muamalah in which the parties to the contract make an agreement as stated in the points of the contract or make an agreement when the contract is already running, the amount of compensation if one of the parties does not implement or is late in carrying out their obligations. So in this amercement clause the amount of compensation has been determined in advance, either when making the contract or in the midst of implementing the agreement, and the amount of the amercement in the agreement does not increase even though the losses suffered by the injured party exceed those suffered or are reduced. This is different from compensation in general, where the amount or amount of the compensation is determined after the party has suffered a loss, or the amount is in accordance with the loss suffered.

Agreements or contracts in general do not escape the inclusion of clauses, which are intended to pressure one party to carry out the contents of the contract/agreement as desired (including the amercement clause) both in agreements relating to accounts payable in financial institutions, both banking and non-bank.

The clause of amercements (syartul jaza'i), is an agreement between the two parties who have a contract to determine the amount of compensation or

${ }^{22}$ First Dictum number 5 DSN-MUI Fatwa 17/2000 
punishment, when they do not carry out the agreement and or when they are late in fulfilling their obligations..$^{23}$

Another definition of the penalty clause (syartul jaza'i) is: a clause contained in a contract or loan agreement or savings instrument regarding the imposition of amercements if the contract conditions are not fulfilled, or delayed loan repayment or withdrawal of time deposits before maturity (penalty). ${ }^{24}$

The review of sharia here can be said to be a review of fiqh, and fiqh is a science that deals with sharia laws that are 'amaly' derived from detailed istinbath arguments. $^{25}$

Islam in addressing the issue of the amercement clause has different opinions among scholars of Madzhab regarding the law including terms/clauses in a contract, there is an opinion that narrows the parties to the contract and there is also an opinion that acquits the contracting party in making the conditions, unless it is clearly stated in the Al-Qur'an. Both the Qur'an and the hadith of the prophet state that this requirement is prohibited.

1) Opinions that narrow the space of the parties to the contract in including the terms/clauses in the contract. The opinion that narrows the parties to the contract in including the terms/clauses in the contract is the opinion of the scholars of Dhohiri experts and Shafi'i Madzhab scholars. However, the scholars of the Shafi'i Madzhab are less lax than the scholars of Dhohiri.

a) Expert opinion Dhohiri. It is clear that among academics, the scholars of dhohiri agree that they only look at what is seen from the texts in taking a proposition, namely the Qur'an and Hadith, and putting aside qiyas. Therefore, it is only natural that they severely limit the inclusion of terms/clauses in the contract, except those that are clearly stated in the Qur'an and Hadith. As the opinion expressed by one of the scholars of Dhohiri expert, Ibn Hazm, namely, any conditions that are not mentioned in the contract when making the contract, have no effect on the contract itself, then the contract is valid and the conditions are invalid. However, if the conditions are stated at the time of making the contract, then the contract and its conditions are invalid, regardless of the types and kinds of conditions except for seven (7) conditions,

b) Opinion of the 'Shafi'i Scholars. Syafi'iyah scholars argue that in this matter, it is true that the law of origin of the terms and contracts is khoqor, and

23'Ifah Abdul Hak. Qoror Wa Tausiyaat Majma' Fiqh Al Islami Ad Dauli Tahun 1988-2013. Muadzomah Mu'tamar Al Islami, Majma' Al Figh Al Islami Ad Dauli, Munadzomah Muktamar Islami Majma' Fiqih Islami Dauli Saudi Arabia. 2009, p.222

${ }^{24}$ Sholikin Ahmad Irfan, Buku Pintar Ekonomi Syariah. Gramedia Pustaka Utama, Jakarta, 2010, p: 411.

${ }^{25}$ Prof. DR. Teungku Muhammad Hasbi Ash Shiddieqy, Pengantar Ilmu Fiqh (Semarang: PT Pustaka Rizki Putra, 1999), p. 16. 
this is not much different from the opinion of the Dhohiri expert, but the opinion of the Shafi'iyah is broader than that of the Dhohiri expert because Shafi'iyah uses the qiyas method in taking the law., if dhohiri experts do not use it at all. Hujah this opinion is a hadith of the prophet who forbids conditions with buying and selling. Imam Shafi'i talks about the meaning of the hadith which says that the condition that is not contained in the text is that the condition for falsehood is a requirement in the marriage contract, such as a woman requiring her husband not to remarry or a man requiring his wife not to provide for him in the marriage contract. , So if someone requires something in the marriage contract, then the condition becomes void and the marriage contract remains valid. The proof on this issue is the bariroh hadith: Imam Shafi'i explains in fact if a woman requires her husband not to marry again during the marriage contract, this condition is contrary to the texts, because Allah and his Messenger allow a husband to marry more than one. Imam Shafi'i allows conditions related to the nature of the contract for the benefit of the contract, such as the conditions in the sale and purchase of slaves, namely that he must be able to write, or in the sale and purchase of livestock, he must be pregnant, so the conditions here are valid along with the contract, because it relates to the benefit of the parties involved. This is one of the exceptions according to Imam Shafi'i because the condition for this trait is at the time of the contract,

2) Opinions that loosen the parties to the contract in including the terms/clauses in the contract. The opinion that gives leeway for the parties to the contract to make conditions is the Imam Hanafi school of thought. In this case, Imam Hanafi is of the view that the origin of the contract and conditions is khoqor, and the principle of this opinion is the hadith of conditions in buying and selling, and he also rejects the interpretation of dhohiril hadith of Jabir's hadith which excludes the principle of benefit as in Imam Shafi'i's opinion. The opinion of Imam Hanafi in this case gives the parties the flexibility to determine the conditions, because it uses the basis of urf, this view is based on the hadith of the prophet narrated by Ibn Mas'ud Ra.

Meaning: from Ibn Mas'ud with the words: verily Allah looks into the hearts of His servants and then chooses the prophet Muhammad and sent him to deliver the tract. Then Allah also looked again into the hearts of His servants, then chose the companions and then made them the helpers of His religion and the assistants of His prophet. Therefore, whatever is considered good by the Muslims, it is also good according to God, and whatever is considered bad by the Muslims is also seen as bad by Allah. (HR Ahmad) ${ }^{26}$

3) An opinion that liberates the parties to the contract in including the terms/clauses in the contract. This opinion is the opinion of the majority of scholars of the Malikiyah and Hanabilah schools. Jumhurul Madzhab malikiyah is of the opinion that it is permissible to allow it in the Mu'awadhoh Maliyah

\footnotetext{
${ }^{26}$ This Hadith was narrated by Ahmad in the book of Sunnah Min Hadith of Abi Wail and is a Hadith of Mauquf Hasan. Head of Jus 12, p. 137
} 
contract and the tabarru' bil ma'dum (the perishable) at the time of the contract. ${ }^{27}$ From this it can be said that the scholars of the Maliki Madzhab give concessions to the contract in general without having to rely on urf. In accordance with the explanation in the previous discussion. Imam Ahmad clearly stated that it is permissible to have conditions in the contract (adding conditions to the contract). ${ }^{28}$ And Imam Ahmad also mentions that the hadith of conditions in buying and selling is a dhoif hadith and cannot be used as a legal proof. From the explanation above, that the sharia law can be categorized into two discussions, namely the sharia law relating to accounts payable and the sharia law which is not related to accounts payable.

The law of the amercement clause in the debt contract is haram because it contains an element of ziyadah to the original nominal value of the debt, and every ziyadah on the original nominal debt is usury, according to the majority of scholars'. And the law of ziyadah is forbidden on the original amount of debt as well as stated in the contract or not.

However, there are also opinions that allow amercement clause in accounts payable contracts, including Shaykh Mustofa Rozak, who states that it is permissible to compensate for losses suffered by dain on madin for delays in paying debts or installments. ${ }^{29}$

Amercements are sanctions or punishments that are applied in the form of having to pay a certain amount of money imposed for the denial of a number of agreements that have been previously agreed upon. There is a difference of opinion among fiqh scholars. Some argue that amercements should not be used, and some argue that they should be used.

The Hambali school of thought, including Ibn Taimiyah and Ibn Qayyim alJawziah, the majority of the Maliki school of thought, the Hanafi school of thought, and some scholars from the Shafi'i school are of the opinion that a judge may impose amercement for a ta'zi crime. ${ }^{30}$ The reason they put forward is a narration from Bahz bin Hukaim who talks about zakat on camels.

Imam al-Shafi'i with al-Qaul al-Jadid, Imam Abu Hanifa and his companion, Muhammad ibn Hasan al-Shayban, as well as some scholars from the Maliki School of thought that amercements should not be imposed in ta'zir. Their reasoning was that the amercements imposed at the beginning of Islam had been ordained (annulled) by the hadith of the Prophet Muhammad. ${ }^{31}$

This late amercement is intended as a sanction or punishment, so as not to

\footnotetext{
${ }^{27}$ Mudawanah Kubro. Juz 15, p. 120

${ }^{28} \mathrm{Ibn}$ Qodamah, Mughoni Juz 1, p. 192

${ }^{29}$ Ibid, p. 411

${ }^{30}$ Halimah, Denda keterlambatan (late charge) pada kartu kredit syariah (studi analisis fatwa DSN MUI no: 54/DSN-MUI/X/2006 tentang Syariah Card), Skripsi Semarang: UIN Walisongo Semarang, 2014, II: 17.

${ }^{31}$ Al-Hafidh Abi Abdullah Muhammad bin Yazizd Al Qozwini, Sunan Ibnu Majjah (Beirūt: Dār alFikr), I: 570, dalam Fathul Aminudin Aziz, Hukum Denda dalam Keuangan Publik Islam di Indonesia, Al-Manahij, Vol. XII No. 2, December 2018
} 
repeat the immoral act again. In the Compilation of Sharia Economic Law, sanctions can be given to people who break their promises, and the provisions of someone called breaking a promise are explained in Article 36, which states that: "A party can be deemed to have broken a promise, if due to his/her fault:

1) Doesn't do what it promises to do.

2) It does what it promises, but not as promised.

3) Did what it promised, but it was too late.

4) Doing something that according to the agreement cannot be done. As for the types of sanctions, it is stated in Article 38, namely: "Parties in the contract who break their promises may be subject to sanctions:

1) Paying compensation

2) Contract cancellation

3) Risk transfer

4) Amercements, and/or

5) Pay court fees. ${ }^{32}$

Amercements are a logical consequence in non-Islamic societies, where trust and trust are rare, the spiritual bond within the individual community fades towards the rules of His creator and weak faith in the certainty of the Day of Judgment. So the logic of sanctions in the form of amercements seems the only and unavoidable to motivate discipline and obedience. ${ }^{33}$

b. The Mechanism of Implementing Amercements in Financing Contracts at Islamic Banks Based on Positive Laws Applicable in Indonesia

1) Application of Amercements in Islamic Bank Financing Contracts Based on the Civil Code

In developing a product, Islamic banks must be guided by sharia principles and consider the existing positive law. ${ }^{34}$

In the Civil Code it is not stated in detail regarding amercements, but Article 1239 of the Civil Code is written regarding reimbursement of costs, losses, and interest, namely:

"Each engagement to do something, or not to do something, if the debtor does not fulfill his obligations, the settlement is in the obligation to provide compensation for costs, losses and interest."

The Civil Code does not mention in detail the imposition and application of amercements. However, if this is stated in the agreement, both parties must comply with the contents of the agreement. The creditor may request the fulfillment of the agreement, or the fulfillment of the agreement accompanied

\footnotetext{
${ }^{32}$ Tim Redaksi Fokusmedia, Kompilasi Hukum Ekonomi Syariah (Bandung: Fokusmedia, 2008), p. 22-23.

${ }^{33} Z a m a k h s y a r i$, Kapita Selekta kasus-kasus Kontemporer dalam timbangan fiqh Islam. Medan: Undhar Press. 2018, p. 121

${ }^{34}$ Wangsawidjaja Z. Pembiayaan Bank Syariah. Jakarta. Kompas Gramedia, 2012, p.36
} 
by compensation and cancellation of the agreement with compensation. The legal basis is Article 1267 of the Civil Code, which reads:

"The party to whom the engagement is not fulfilled, can choose; compel the other party to fulfill the agreement, if it can still be done, or demand the cancellation of the agreement, with reimbursement of costs, losses and interest."

2) Provisions for Amercements in Sharia Bank Financing Agreements Based on Fatwa of the National Sharia Council - Indonesian Ulema Council

Penalty provisions (ta'zir) regulated in fatwa no.17/DSN-MUI/IX/2000 concerning sanctions on well-off customers who deliberately delay payments. According to the fatwa stipulated by DSN-MUI, the imposition of amercements imposed by DSN-MUI follows the views and opinions of the scholars of Abu Yusuf al-Hanafi and Imam Malik bin Anas who allow the application of this amercement because the application of amercements has benefits for people who provide loans to people. People who are reluctant to pay their debts even though they are able to pay them.

The sanctions referred to in this fatwa are sanctions imposed by Islamic banks on customers who are able to pay, but deliberately delay payments. Customers who are unable/unable to pay due to force majeure may not be penalized. Able customers who delay payments and/or do not have the will and good faith to pay their debts may be subject to sanctions. Sanctions are based on the principle of ta'zir, which aims to make customers more disciplined in carrying out their obligations. Sanctions can be in the form of a amercement of money, the amount of which is determined on the basis of an agreement and made when the contract is signed. Funds derived from amercements are designated as social funds. ${ }^{35}$

3) Setting amercements in the Islamic Bank Financing Agreement based on the Sharia Economic Law Compilation

The birth of Act No. 3 of 2006 concerning Amendments to Act No. 7 of 1989 concerning Religious Courts has brought major changes to the position and existence of religious courts in Indonesia. In addition to the authority that has been given in the field of Islamic Family Law, the religious courts are also given authority which includes sharia banking in the field of sharia economics, and sharia medium-term securities, sharia securities, sharia financing, sharia pawnshops, Islamic financial institution pension funds, and business. ${ }^{36}$

KHES is issued in the form of Supreme Court (Perma) regulation No. 2 of 2008 concerning the Compilation of Sharia Economic Law. This KHES has undergone adjustments to existing sharia provisions, such as the DSN (National Sharia Council) fatwa.

Sociologically, KHES was structured as a response to new developments in

${ }^{35}$ DSN-MUI Fatwa No. 17/DSN-MUI/IX/2000

${ }^{36}$ Zinuddin Ali, Hukum Ekonomi Syariah, Jakarta.Sinar Grafika. 2008, p.13 
muamalat in the form of Shari'a economic practices through LKS-LKS that require a legal law. ${ }^{37}$

The Sharia Economic Law Compilation also allows the application of sanctions in the form of amercements to customers who are late in making payments. In its application, it is contained in the fourth chapter on breaking promises of article 38 of the KHES which contains various kinds of sanctions that can be applied to customers who are late in making payments. The amercements are not regulated in detail in the KHES, only mentioned as a form of various kinds of sanctions that can be applied to customers or debtors who break their promises. The regulation regarding amercements in this KHES is only a reference that amercements are allowed for customers who break their promises. However, more detailed arrangements regarding the application of the amount of amercements given to customers are regulated in the Sharia Bank regulations.

4) Setting Amercements in Islamic Bank Financing Contracts Based on Financial Services Authority Regulations

Islamic banks in carrying out their operations must be based on sharia principles that are sourced from the Qur'an and sunnah, in addition to complying with applicable laws, they must also comply with the Fatwa issued by the National Sharia Council in which the issued fatwa will have the same position as the positive law in Indonesia. Whereas every product in a sharia bank must first obtain approval from the Sharia Supervisory Board and a fatwa from the National Sharia Council as well as approval from Bank Indonesia. However, since the issuance of Act No. 21 of 2011 concerning the Financial Services Authority, currently the regulation and supervision of banking, including sharia banking, is under the Financial Services Authority. ${ }^{38}$

Provisions related to amercements on murabahah can also be found in the Murabahah Product Standard Book issued by the Financial Services Authority (OJK). The provisions regarding sanctions that can be given to defaulting customers as stated in the Murabahah Product Standard Book issued by the OJK are in accordance with the provisions stipulated by the DSN-MUI Fatwa.

c. How is the Implementation of Amercements in Islamic Banking Financing Contracts Against the Principles of Justice and Benefit

The principle of justice that is relevant to this research is distributive justice. According to Aristotle, justice is divided into two types of justice, namely distributive justice and commutative justice. Distributive justice is justice that gives achievement to each person according to his achievements. Commutative justice gives equal amount to everyone regardless of their achievements. ${ }^{39}$

\footnotetext{
${ }^{37}$ Abdul Mughits, Kompilasi Hukum Ekonomi Syari'ah (KHES) dalam Tinjauan Hukum Islam, Jurnal Al-Mawarid Ed. XVIII, p. 157

${ }^{38}$ Otoritas Jasa Keuangan, Buku Standar Produk Murabahah, p. v

${ }^{39}$ L.J Van Apeldoorn, 1996, Pengantar Ilmu Hukum, Jakarta, Pradnya Paramita, p. 11-12.
} 
While the principle of justice according to the Islamic view is justice that comes from the conception and outlined by Allah SWT in the Qur'an and the Sunnah of the Prophet which must be applied by all humans in their lives so that they can realize a happy, peaceful and prosperous life in this world and in the hereafter as they wish. ${ }^{40}$ According to QS An-Nahl verse 90:

"Verily Allah has commanded (you) to act" just and do good, give to relatives, and Allah forbids from evil deeds, evil and enmity. He teaches to you so that you may learn a lesson."

In Al-Quran Surah An-Nisa verse 135 Allah SWT commands humans so that humans uphold justice, be fair witnesses even against themselves, parents and family. Justice according to the letter An-Nisa verse 135:

"O you who believe, be true enforcers of justice, be witnesses for Allah, even if it is against yourself or your parents and your relatives. If he is rich or poor, then Allah knows best his benefit. So do not follow your lust because you want to deviate from the truth. And if you twist (words) or refuse to be witnesses, then surely Allah is Knowing of all that you do."

The perception of Islamic justice theory can be applied if the meaning of justice is flexible. This means that everyone has the right to receive justice as in the life of transactions in the Islamic economy. Distributive justice is justice in which everyone gives a portion to perform an achievement in accordance with the capacity of the rights that arise.

Fair also means taking sides or holding on to the truth. With the various contents of the meaning of "fair", broadly justice can be deamercementd as a condition where there is equality of treatment in the eyes of the law, equal rights of compensation, rights to live properly, rights to enjoy development and the absence of aggrieved parties and balance in every aspect of life. . Islam deamercements justice as "not oppressing and not being oppressed." The economic implication of this value is that economic actors are not allowed to pursue personal gain if it harms other people or destroys nature. Without justice, humans will be divided into various groups. One group will oppress other groups, resulting in human exploitation of humans. In other Islamic treasures, the justice in question is divine justice, namely justice that is not separate from morality, based on absolute values revealed by Allah SWT and human acceptance of these values is an obligation. Based on the content of the meaning of 'Adl contained in the Qur'an, several derivative values were derived, namely: compensation equation, legal equality, moderate, and proportional. ${ }^{41}$

Amercements cannot be recognized as operating or non-operating income because they have an element of injustice. Whereas the substance of sharia

\footnotetext{
${ }^{40}$ Nurdin, 2011, Konsep Keadilan \& Kedaulatan Dalam Perpektif Islam \& Barat, Media Syariah Vol. XIII No. 1 January-June.

${ }^{41}$ Muchlish Khomayny, Muhammad Wahyuddin Badullah, Perlakuan Denda Pembiayaan Berbasis Konsep Al-Adl Dalam Menjaga Eksistensi Bisnis Bank Syariah, Jurnal lqtisaduna, volume 6 Nomor 2 Ed. December 2020, p. 91-103
} 
economics is justice and virtue. Injustice will occur if the Islamic bank / creditor directly imposes a amercement on the customer without first investigating the cause of the non-fulfillment of obligations. Therefore, sharia entities are required to make disclosures on amercement transactions even though the amount is not material.

Late penalties are not included in usury if the definition of usury is the benefits received by creditors for loan services provided to debtors. This is as the rules of fiqh: "That every benefit taken by the creditor (the party who lends money) for his loan services is included in the category of usury." Meanwhile, late funds are not income for Islamic banks, but are social funds intended for the poor and other entitled. ${ }^{42}$

\section{d. Hypothesis}

Based on the theories and research findings according to the researcher's review, the imposition of amercements by Islamic banks has in fact caused controversy among the public. If you pay attention to the amercement, it is almost similar to interest that will rub against usury. The difference between a penalty and interest is recognition and calculation. If a amercement is imposed on the grounds that the customer is late in paying the installments, interest is charged on the customer's loan. Likewise, amercements have been set at the beginning of the contract, while interest rates are uncertain, following the inflation rate.

The amercements are used for social activities. Social funds originating from amercements are still in the control of the bank so they are prone to misuse so that the value of social benefits is still questionable. Funds originating from amercements are non-halal income for Islamic banks so they should not be included in Islamic bank income. The imposition of amercements creates additional money that will come into contact with usury. The addition in the form of money will certainly be contrary to sharia principles.

The implementation of sharia principles must really be carried out, considering that Islamic banks are not only banks with sharia labels but also banks that become mediators to carry out da'wah in the field of sharia business and economics and carry out banking operations based on the provisions of Islamic law. As reinforced in Article 2 of Act No. 21 of 2008 concerning Islamic Banking that Islamic banking in conducting its business activities is based on sharia principles, economic democracy and the principle of prudence. Elucidation of Article 2 of Act No. 21 of 2008 concerning Islamic Banking is further elaborated on the meaning of sharia principles. The purpose of business activities based on

\footnotetext{
${ }^{42}$ Zawawi. 2016. Fatwa klausul sanksi dalam akad: studi komparatif fatwa Dewan Syariah Nasional (DSN) Majelis Ulama Indonesia (MUI) \& Majma' Fiqh Organisasi Konferensi Islam (OKI), ljtihad, Jurnal Wacana Hukum Islam \& Kemanusiaan. Vol. 16, No. 2 (2016), p. 237-255, doi : 10.18326/ijtihad.v16i2.237-255.
} 
sharia principles is business activities that do not contain elements of maysir (gambling), gharar (uncertainty), usury (interest), dzalim and illicit goods.

\section{Closing}

1) Amercements imposed on customers/debtors who are negligent or fail to comply with the agreement contained in the financing contract, this is indeed an effective effort as a form of emphasis so that the customer always fulfills the agreed agreement. However, shari'ah in viewing a law is not only based on voluntary principles and effectiveness or benefits but also there are provisions and limitations that make this form of muamalah permissible or not, in accordance with fiqh rules. Based on the opinion of the majority of scholars', amercements for lateness, negligence and breaking promises are not allowed by syara', when the original obligation is in the form of debts or even payments, because the amercement can be categorized as usury and the law becomes usury, so it is forbidden by sharia. Unlike the case when the original obligation is not in the form of debts or payments, this is allowed by syara'. 2) Legal arrangements regarding the application of amercements for late payment of debts are based on: First, the Civil Code does not mention in detail the imposition of amercements. If this is stated in the agreement, both parties must comply with the contents of the agreement. However, there are provisions regarding compensation, this is regulated in Article 1267 of the Civil Code. Second, the DSN-MUI Fatwa allows Islamic banks to apply sanctions in the form of amercements of a certain amount of money for customers who delay paying debts when they can afford it. The provision for amercements is regulated in fatwa no.17/DSN-MUI/IX/2000 concerning sanctions on well-off customers who deliberately delay payments. Third, the Sharia Economic Law Compilation (KHES) allows the application of sanctions in the form of amercements to customers who are late in making payments. This is regulated in article 38 of the KHES. Third, the Sharia Economic Law Compilation (KHES) allows the application of sanctions in the form of amercements to customers who are late in making payments. This is regulated in article 38 of the KHES. Fourth, the Financial Services Authority regulates provisions related to amercements on murabahah in the Murabahah Product Standard Book issued by the Financial Services Authority (OJK). Regarding amercements, there are points 3.19 regarding Default Standards and 3.20 concerning Amercements Standards of (Ta'zir). 3) Amercements cannot be recognized as operating or non-operating income because they have an element of injustice. Whereas the substance of sharia economics is justice and virtue. Injustice will occur if the Islamic bank / creditor directly imposes amercement on the customer without first investigating the cause of the arrears of the obligation. Therefore, sharia entities are required to make disclosures on amercement transactions even though the amount is not material. 


\section{References}

Al Qur'an and Hadith

Journals:

[1] A Chuasanga, Ong Argo Victoria. (2019). Legal Principles Under Criminal Law in Indonesia and Thailand, Jurnal Daulat Hukum, Vol 2, No 1 (2019) http://jurnal.unissula.ac.id/index.php/RH/article/view/4218

[2] Al-Hafidh Abi Abdullah Muhammad bin Yazizd Al Qozwini, Sunan Ibnu Majjah (Beirūt: Dār al-Fikr), I: 570, dalam Fathul Aminudin Aziz, Hukum Denda dalam Keuangan Publik Islam di Indonesia, Al-Manahij, Vol. XII No. 2, December 2018

[3] Al-Sadiqi Muhammad al-Amin al-Darir. 'al-Ittifaq 'ala lizam al-Madin alMu'sir bi Ta'wid Darar al-Mumtalah. Journal of Research in Islamic Economics. Vol. 3, No. 1. (1985), hal. 111-112 lihat pada Kholis. Urgensi ljtihad Akademik

[4] Al-Syatibi, Al-Muwafaqat fi Ushul Al-Syari'ah, Kairo: Mustafa Muhammad, t.t. II: 4. dalam Auffah Yumni, Kemaslahatan Dalam Konsep Maqashid AlSyari'ah, NIZHAMIYAH, Vol. VI, No.2, 2016

[5] Antonio, M. S., Sanrego, Y. D., \& Taufiq, M. (2012). An Analysis of Islamic Banking Performance: Maqashid Index Implementation in Indonesia and Jordan. Journal of Islamic Finance

[6] Auda, J. (2008). Maqasid Al-Shariah: An Introductory Guide. International Institute of Islamic Thought, dalam Adinda Vindri Andriana Rini, Analisis Kinerja Perbankan Syariah Dengan Maqasid Based Performance Evaluation Model

(MPEM), http://journal.unj.ac.id/unj/index.php/wahana-akuntansi , Jurnal Ilmiah Wahana Akuntansi, Vol 13 (1) 2018

[7] C.S.T. Kansil, 1977, Pancasila \& UUD 1945: dasar falsafah negara, Jakarta: Pradnya Paramita, h. 55. Dalam Anis Mashdurohatun, Zaenal Arifin, Gunarto, 2016, Rekonstruksi Parate Eksekusi Hak Tanggungan: atas tanah yang berkeadilan, Semarang: Unissula Press

[8] Chapra, U. (2016). The Future of Economics: An Islamic Perspective. Leicester: The Islamic Foundations, dalam Adinda Vindri Andriana Rini, Analisis Kinerja Perbankan Syariah Dengan Maqasid Based Performance Evaluation Model

(MPEM), http://journal.unj.ac.id/unj/index.php/wahana-akuntansi , Jurnal Ilmiah Wahana Akuntansi, Vol 13 (1) 2018

[9] Deen, Thaufiq., Ong Argo Victoria \& Sumain. (2018). Public Notary Services In Malaysia. JURNAL AKTA: Vol. 5, No. 4, 1017-1026. Retrieved from http://jurnal.unissula.ac.id/index.php/akta/article/view/4135

[10] Halimah, Denda keterlambatan (late charge) pada kartu kredit syariah (studi analisis fatwa DSN MUI no: 54/DSN-MUI/X/2006 tentang Syariah Card), Skripsi Semarang: UIN Walisongo Semarang, 2014 
[11] Hurayra, M. (2015). Achievement of Maqasid al- Shari'ah in Islamic Banking: An Evaluation of Islami Bank Bangladesh Limited. Global Journal of Computer Science and Technology: A Hardware and Computation, 15(1), 8-16. dalam Andriana, Adinda Vindri \& Rini. (2018). Analisis Kinerja Perbankan Syariah dengan Maqasid Based Performance Evaluation Model (MPEM). Jurnal Ilmiah Wahana Akuntansi, 13(1), 73-103. http://doi.org/10.21009/wahana.013.1.6

[12] Ibn Ashur, M.-T. (2013). Ibn Ashur Treatise on Maqasid al-Shari'ah. Herndon: International Institute of Islamic Thought, dalam Adinda Vindri Andriana Rini, Analisis Kinerja Perbankan Syariah Dengan Maqasid Based Performance Evaluation Model (MPEM), http://journal.unj.ac.id/unj/index.php/wahana-akuntansi , Jurnal IImiah Wahana Akuntansi, Vol 13 (1) 2018

[13] Ibn Hajar Al Asqolani. Fathu Barri. Beirut. Arrisalah Al Alamiyah Juz 5 P. 657 dalam Muhammad Sulthon Aziz, Tinjauan Syari'ah terhadap Klausul Denda pada Perjanjian (Akad), Jurnal El-Faqih, Volume 3, Nomor 2, Oktober 2017

[14] Ibn Qayyim al-Jauziyyah. I'lam al-Muwaqqi'in. (Beirut: Dar alKutub al-IImiyyah, 1996M). Jld. 3, m.s. 37 dalam Suherman (Ketua Kantor Urusan Agama (KUA) Subang), Penterapan Prinsip Bagi Hasil Pada Perbankan Syariah Sebuah Pendekatan Al-Maqasidu Al-Syariah, Al Mashlahah Jurnal Hukum \& Pranata Sosial Islam.

[15] M. Syamsudin, Operasionalisasi Penelitian Hukum, (Jakarta, PT Rajarafindo Persada, 2007), p. 114, dalam Husain Asmara, "Peran NotarisPPAT Dalam Pembuatan Akta Pembiayaan Kepemilikan Rumah Melalui Bank Syariah" ,Tesis Program Studi Magister Kenotariatan Fakultas Hukum Universitas Islam Indonesia, 2018

[16] M. Umer Chapra and Tariqullah Khan (2000), Regulation and Supervision of Islamic Banks, (Jeddah: Islamic Research and Training Institute and Islamic Development Bank, hal. 89 lihat juga Kholis. Urgensi ljtihad Akademik

[17] Maslahah 'ammah (public interest) maksudnya adalah untuk kepentingan \& kemaslahatan umat, Mohammad Ali Elgari, Mohammad Nejatullah Siddiqi and Mohammad Anas Zarqa (1993) ,"Qanun al-MasarifSighah Muqtarahah li-Tanzim Qita'fi al-Masraf al-Islami,"Review of Islamic Economics, Vol. 2, No. 2. (1993), hal. 67-97 sebagaimana dikutip oleh Kholis. Urgensi ljtihad Akademik.

[18] Mohammed, M. O., \& Taib, F. M. (2015). Developing Islamic Banking Measures Based on Maqasid Al-Shariah Framework: Cases of 24 Selected Banks. Journal of Islamic Monetary Economics and Finance, 5577, dalam Adinda Vindri Andriana Rini, Analisis Kinerja Perbankan Syariah Dengan Maqasid Based Performance Evaluation Model (MPEM), 
http://journal.unj.ac.id/unj/index.php/wahana-akuntansi , Jurnal IImiah Wahana Akuntansi, Vol 13 (1) 2018

[19] Mohammed, M. O., Razak, D. A., \& Taib, F. M. (2008). The Performance Measures of Islamic Banking Based on the Maqasid Framework. IInternational Accounting Conference IV (p. 1-17). Putrajaya: International Islamic University Malaysia, dalam Adinda Vindri Andriana Rini, Analisis Kinerja Perbankan Syariah Dengan Maqasid Based Performance Evaluation Model (MPEM), http://journal.unj.ac.id/unj/index.php/wahana-akuntansi , Jurnal IImiah Wahana Akuntansi, Vol 13 (1) 2018

[20] Muchlish Khomayny, Muhammad Wahyuddin Badullah, Perlakuan Denda Pembiayaan Berbasis Konsep Al-Adl Dalam Menjaga Eksistensi Bisnis Bank Syariah, Jurnal Iqtisaduna, volume 6 Nomor 2 Ed. December 2020

[21] Muhammad bin Ismail al-Kahlani, al-Shan'ani, Subul al-Salam, Juz ke 3, (Bandung: Dahlan Thaba' 'ala Nafaqah, tt.), hal. 61 sebagaimana dikutip oleh Maimun. Sanksi terhadap Debitur Pengemplang Praktik Perbankan Syariah: Suatu Kajian Aplikatif Pendekatan Ushul Fiqh. Fakultas Syariah IAIN Raden Intan Lampung

[22] Ni Ketut Supasti Dharmawan, 2006, Metodologi Penelitian Hukum Empiris, Makalah Kedua dipresentasikan pada Lokakarya pascasarjana Universitas Udayana

[23] Nor Azzah Kamri Fadillah Mansor. Aplikasi Konsep al-Murâbahah dalam Penawaran Instrumen di Institusi Perbankan Islam di Malaysia. API UM. Kuala Lumpur, hal. 138 lihat juga Nur Kholis. Urgensi ljtihad Akademik dalam Menjawab Problematika Muamalah Kontemporer, AlMawarid Ed. XIV. (2005)

[24] Ong Argo Victoria, Ade Riusma Ariyana, Devina Arifani. (2020). Code of Ethics and Position of Notary in Indonesia. Sultan Agung Notary $\begin{array}{llll}\text { Law } & \text { Review } & 2 & (4), \quad 397-407, \quad \text { http://lppm- }\end{array}$ unissula.com/jurnal.unissula.ac.id/index.php/SANLaR/article/view/13536

[25] Rawwas Q, Ensiklopedi Fiqh Umar Bin Khattab ra, (Beirut: Dar al fikr, Tt), hal. 578 dikutip dari Pedagogita Rakhmah. Penerapan Akad Murabahah dengan Tambahan Denda pada Kelompok UKM Binaan di Bank Tabungan Pensiunan Nasional (BTPN) Syariah Surabaya dalam Tinjauan Hukum Islam. Vol. 05, No. 01, June (2015)

[26] Resolution No. 53 Vth Annual Session. Jeddah. Journal No. 6, Vol. I, hal. 447 dikutip oleh Muhammad Taqi Usmani (2002), An Introduction to Islamic Finance (London: Kluwer Law Internasional), hal. 58 lihat juga pada Kholis. Urgensi ljtihad Akademik

[27] Suma, Muhammad Amin. 2002. "Ekonomi Syariah Sebagai Alternatif Sistem Ekonomi Konvensional”, Jurnal Hukum Bisnis, Vol. XX 
[28] Yaya Kareng, Ong Argo Victoria, R. Juli Moertiyono. (2019). How Notary's Service in Thailand. Sultan Agung Notary Law Review, 1 (1), 4656, http://jurnal.unissula.ac.id/index.php/SANLaR/article/view/4435

[29] Zawawi. 2016. Fatwa klausul sanksi dalam akad: studi komparatif fatwa Dewan Syariah Nasional (DSN) Majelis Ulama Indonesia (MUI) \& Majma' Fiqh Organisasi Konferensi Islam (OKI), Ijtihad, Jurnal Wacana Hukum Islam \& Kemanusiaan. Vol. 16, No. 2 (2016), p. 237-255, doi : 10.18326/ijtihad.v16i2

Books:

[1] Abdul Aziz Dahlan, Ensiklopedi Hukum Islam, Print. VI, Jakarta : Ichtiar Baru Van Hoeve, 2003

[2] Abdul Qadir Audah At-tasyri' Al-Jina Al-Islamiy Muqaranan bil Qanunil Wadi'iy, Ter. Tim Tsalisah, Ensiklopedi Hukum Islam. Bogor : PT.Kharisma IImu

[3] Abu Ali Ahmad Ibn Miskawaih, 1994, Menuju Kesempurnaan Akhlak: buku daras pertama tentang filsafat etika, Bandung: Mizan

[4] Achmad Ali, 2010, Menguak Realitas Hukum: rampai kolom \& artikel pilihan dalam bidang hukum, Jakarta: Kencana

[5] Adiwarman Karim, Bank Islam; analisis fiqih \& keuangan, (Jakarta: Raja Grafindo Persada, 2010)

[6] Ahmad Azhar Basyir, Asas-Asas Hukum Muamalat (Hukum Perdata Islam),(Yogyakarta,UII Press,2009)

[7] Ahmad Ifham Sholihin, Buku Pintar Ekonomi Syariah, ( Jakarta: PT. Gramedia Pustaka Utama Kompas Gramedia Building, 2010)

[8] Ahmad Kamil \& Fauzan, Kitab Undang-Undang Hukum Perbankan \& Ekonomi Syariah, (Jakarta: Kencana, 2007)

[9] Ahmed, S., Rahman, M., Ahmed, S., \& Wali, G. (2014). Pricing Linkage Between Islamic Banking and Conventional Banking: The Case of Bangladesh. International Journal of Finance \& Banking Studies

[10] Andri Soemitra, Bank \& Lembaga Keuangan Syariah, (Jakarta: Kencana, 2014)

[11] Andrieansjah Soeparman, 2012, Hak Desain Industri Berdasarkan Penilaian Kebaruan Desain Industri, Bandung: PT. Alumni

[12] Aliminsyah \& Padji, Kamus Istilah Keuangan \& Perbankan Yrama Widya

[13] Bambang Sunggono, Metodologi Penelitian Hukum, (Jakarta : PT. Raja Grafindo Persada, 2003)

[14] Bahder Johan Nasution, 2004, Hukum Ketenagakerjaan Kebebasan Berserikat Bagi Pekerja, Bandung: Mandar Maju

[15] Bentham, J. (2005). An Introduction to The Principle of Morals and Legislation. Oxford: Clarendon Press. 
[16] Burhan Ashshofa, Metodologi Penelitian Hukum, Print. Ketiga, (Jakarta : PT. Rineka Cipta, 2001)

[17] Burhan Ashshofa, 2004, Metode Penelitian Hukum, Jakarta: Rineka Cipta

[18] Daryanto, Bahasa Kamus Indonesia Lengkap, Surabaya, Penerbit APOLLO, 1997

[19] Dewan Syariah Nasional MUI, Fatwa Dewan Syari'ah Nasional No: 17/DSN-MUI/IX/2000

[20] Departemen Agama RI, Al-Hikmah Al-qur'an \& Terjemahnya, (Bandung: CV Penerbit Diponegoro, 2008)

[21] Endang Sutrisno, 2007, Bunga Rampai Hukum \& Globalisasi, Jakarta: Genta Press

[22] Fernando M. Manullang, 2007, Menggapai Hukum Berkeadilan, Jakarta: Kompas

[23] Farida, \& Zuliani, N. L. (2015). Pengaruh Pengembangan Dimensi Pengetahuan, Peningkatan Keterampilan Baru \& Kesadaran Masyarakat terhadap Kinerja Maqasid. Cakrawala

[24] Fokky Fuad Wasitaatmadja, Filsafat Hukum Akar Religiositas Hukum, Ctk. Kedua, Kencana, Jakarta, 2017

[25] Habib Adjie \& Muhammad Hafidh, Akta Perbankan Syariah Yang Selaras Pasal 38 UUJN, (Semarang, PT Pustaka Rizki Putra,2014)

[26] Harisman, Perkembangan Perbankan Syariah: Kini \& Esok, Dalam Hamidi, 2003, Jejak-Jejak Ekonomi Syaraiah, (Jakarta, Senayan Abadi Publising, 2003)

[27] Hirsanudin, Hukum Perbankan Syariah di Indonesia, (Yogyakarta, Genta Press,2008)

[28] HMA Kuffal., 2012, Demi Keadilan Berdasarkan Ketuhanan Yang Maha Esa, Malang: Universitas Muhammadiyah Malang

[29] Hyronimus Rhiti, Filsafat Hukum Ed. Lengkap (Dari Klasik ke Postmodernisme), Ctk. Kelima, Universitas Atma Jaya, Yogyakarta, 2015

[30] Ibnu Abidin, rad al-mukhtar "alal ardh al-mukhtar, VI, p. 19. \& 50; Bidayatul Mujtahid wa Nihayatul Muqtashid, II, p. 211. \& Adiwarman A, Karim, Bank Islam: Analisis Fiqihdan keuqgqn, (Jakarta: Raja Grafindo, 2004)

[31] Inosentius Samsul, 2004, Perlindungan Konsumen, Kemungkinan Penerapan Tanggungjawab Mutlak, Depok: Universitas Indonesia, Fakultas Hukum, Pascasarjana

[32] Ismail, Perbankan Syariah, (Jakarta: Kencana Prenada Media Group, 2011)

[33] Jallaludin As-Suyuti, Sunan AN-Nasa'l, jilid: V, Beirut: Darul Qutub Ulumiah 
[34] John Rawls, 2006, Teori Keadilan: dasar-dasar filsafat politik untuk mewujudkan kesejahteraan social dalam negara, Yogyakarta: Pustaka Pelajar

[35] John Pieris, Wiwik Sri Widiarty, 2007, Negara Hukum \& Perlindungan Konsumen Terhadap Produk Pangan Kedaluarsa, Jakarta: Pelangi Cendikia

[36] Johnny Ibrahim, Teori \& Penelitian Hukum Normatif, (Malang :, Bayumedia Publishing, print.2, 2006)

[37] Juhaya S. Praja, Filsafat Hukum Islam, ctk. Pertama, Pusat Penerbitan Universitas LPPM- Universitas Islam Bandung, Bandung, 1995

[38] J.Sudarminta, Etika Umum: Kajian Tentang Beberapa Masalah Pokok \& Teori Etika Normatif (Yogyakarta: Kanisius, 2013)

[39] Kaelan, A. Zubaidi, 2016, Pendidikan Kewarganegaraan Untuk Perguruan Tinggi, Yogyakarta: Paradigma

[40] Kamil, Ahmad \& Fauzan, M, 2007, Kitab Undang-Undang Hukum Perbankan \& Ekonomi Syariah, Kencana Prenada Media Group, Jakarta

[41] Kamus Besar Bahasa Indonesia, Ed. VI, DEPDIKNAS, 2012

[42] Ketut Rindjin, 2012, Pendidikan Pancasila Untuk Perguruan Tinggi, Jakarta: PT. Gramedia Pustaka Utama

[43] Khairandy, Ridwan, 2006, Hukum Pasar Modal, UII Press, Yogyakarta

[44] K. Bertens, Pengantar Etika Bisnis (Yogyakarta: Kanisius, 2015)

[45] Lili Rasjidi, Ida bagus Wyasa Putra, 2003, Hukum Sebagai Suatu Sistem, Bandung: Mandar Maju

[46] Mardani, Hukum Perikatan Syariah di Indonesia, (Jakarta, Sinar Grafika,2013)

[47] Mardani, Fiqh Ekonomi Islam: Fiqh Muamalah, (Jakarta: Kencana, 2012)

[48] Marzuki, Metodologi Riset, (Yogyakarta : BPFE UII, 2003)

[49] Mohal Nazir, Metode Penelitian, (Jakarta : Ghalia Indonesia, 1998)

[50] Moh Kasim Bakri, Hukum Pidana dalam Islam, Semarang : Ramadhani, 1958

[51] Muhammad Syukri Albani Nasution, Hukum dalam Pendekatan Filsafat, Ctk. Kedua, Kencana, Jakarta, 2017

[52] Muhammad, Bank syariah: analisis kekuatan, kelemahan, peluang, \& ancaman, (Yogyakarta: Ekonisia, 2002)

[53] M. Syafi'i Antonio, Bank Syariah dari Teori ke Praktek, (Jakarta: Gema Insani, 2001)

[54] Mochtar Kusumaatmadja, 1970, Fungsi \& Perkembangan Hukum Dalam Pembangunan Nasional, Bandung: Fakultas Hukum, Universitas Padjadjaran 
[55] Muhammad Syafi'i Antonio, Bank Syari'ah dari Teori ke Praktek, Gema Insani, Jakarta, 2001

[56] M. Syafi"i Antonio, Bank Syariah: dari teori ke praktik, (Jakarta: Gema Persada Press, 2014)

[57] M. Agus Santoso, Hukum, Moral \& Keadilan Sebuah Kajian Filsafat Hukum, Ctk. Kedua, Kencana, Jakarta, 2014

[58] M. Nurul Irfan \& Masyofah, Fiqh Jinayah, (Jakarta: AMZAH, 2013)

[59] M. Latifa and Lewis, Mervyn k. Algout, Islamic Banking, Edward Elgar, Massachusset, diterjemahkan oleh Burhan Wisnubrata, Perbankan Syariah, Prinsip, Praktik, Prospek (Jakarta: Serambi, 2001)

[60] Otong Rosadi, 2012, Quo Vadis Hukum, Ekologi, Keadilan Sosial dalam Perenungan Pemikiran (Filsafat) Hukum, Yogyakarta: Thafa Media

[61] Peter Mahmud Marzuki, Penelitian Hukum, (Jakarta: Kencana Prenada Media Group, 2000)

[62] Prof. DR. Teungku Muhammad Hasbi Ash Shiddieqy, Pengantar Ilmu Fiqh (Semarang: PT Pustaka Rizki Putra, 1999)

[63] P. Joko Subagyo, Metode Penelitian dalam Teori \& Praktek, (Jakarta : PT. Rineka Cipta, 1997)

[64] Romli Atmasasmita, 2012, Teori Hukum Integratif: rekonstruksi terhadap teori hukum pembangunan \& teori hukum progresif, Yogyakarta: Genta Publishing

[65] Ronny Hanitijo Soemitro, "Metodologi Hukum \& Julimetri", (Jakarta : Ghalia Indonesia, 1990)

[66] Salam Maryadi, Kamus Haji \& Umrah, (Jakarta: Kubah Hijau, 2007)

[67] Satjipto Rahardjo, Ilmu Hukum, Ctk. Kedelapan, Citra Aditya Bakti, Bandung, 2014

[68] Satjipto Rahardjo, 2009, Hukum Progresif: sebuah sintesa hukum Indonesia, Yogyakarta: Genta Pub

[69] Satjipto Rahardjo, 2005, Hukum Progresif, Hukum Yang Membebaskan, Jurnal Hukum Progresif, PDIH Semarang, Vol 1, No 1 (2005)

[70] Sayyid Sabiq, Fikih Sunnah 10, (Bandung: Al-Maarif, 1978)

[71] Sholikin Ahmad Irfan, Buku Pintar Ekonomi Syariah. Gramedia Pustaka Utama, Jakarta,Tahun 2010

[72] Sula, Muhammad Syakir, 2004, Asuransi Syariah (Life \& General), Konsep \& Sistem Operasional, Gema Insani Press, Jakarta

[73] Sutan Remy Syahdeni, Perbankan Islam \& Kedudukanya Dalam Tata Hukum Perbankan Indonesia (Jakarta: Pustaka utama grafiti, 1999)

[74] Sutrisno Hadi, Metodologi Research", Jilid I, (Yogyakarta : ANDI, 2000)

[75] S. Margono, Metodologi Penelitian Pendidikan, (Jakarta : Rineka Cipta, 2003) 
[76] Soerjono Soekanto, 2001, Sosiologi Suatu Pengantar, Jakarta: PT. Raja Grafindo Persada

[77] Sutan Remy Sjahdeini, 1993, Kebebasan Berkontrak \& Perlindungan Yang Seimbang Bagi Para Pihak Dalam Perjanjian Kredit Bank, Jakarta: Institut Bankir Indonesia, sebagaimana dikutip dari Timothy P. Hilton, dkk., Applied Social Research, New York: Springer Publishing Company

[78] Sudarminta, Etika Umum: Kajian Tentang Beberapa Masalah Pokok \& Teori Etika Normatif

[79] Syamsul Anwar, Studi Hukum Islam Kontemporer, Print. Ke 1, (Jakarta: RM. Book, 2007)

[80] Tim Redaksi Fokus media, Kompilasi Hukum Ekonomi Syariah, (Bandung: Fokus media, 2008)

[81] Veithzal Rivai, dkk, Islamic Economics: Eknomi Syariah Bukan Opsi, Tetapi Soslusi. (Jakarta: Bumi Aksara.2009) Veithzal Rivai, dkk, Islamic Economics: Eknomi Syariah Bukan Opsi, Tetapi Soslusi. (Jakarta: Bumi Aksara.2009)

[82] Wahbah al-Zuhayly, Fiqih Islam 7 (Sistem Ekonomi Islam, Pasar Keuangan, Hukum Hadd Zina \& Pencurian), (Jakarta: Gema Insani, 2011), hal. 530-531 diterjemahkan oleh Abdul Hayyie al-Kattani, dkk, disunting oleh Arif Muhajir, Print. 1

[83] Wiroso, Jual Beli Murabahah, (Yogyakarta:UII Press, 2005)

[84] W. J. S. Poerwadarminta, 1966, Kamus Umum Bahasa Indonesia, Volume 1, Jakarta: P.N. Balai Pustaka

[85] Yuslam Fauzi, Memaknai Kerja, (Jakarta: Mizan, 2012)

\section{Regulations:}

[1] Act No. 21 of 2008 concerning Sharia Banking

[2] Act No. 21 of 2011 concerning the Financial Services Authority

[3] Act No. 3 of 2006 concerning Amendments to Act No. 7 of 1989 concerning Religious Courts

[4] Code of Civil law, 2014, Surabaya: Sinarsindo Utama

[5] Fatwa of the National Sharia Council No.17/DSN-MUI/IX/2000 Regarding Sanctions on Able Customers Who Deliberately Delay Payments

[6] MUI National Sharia Council, National Sharia Council Fatwa No: 17/DSNMUI/IX/2000

[7] Subekti, R., Tjitrosudibio, R., Burgerlijk Wetboek Civil Code, Balai Pustaka

[8] Supreme Court Regulation (Perma) No. 2 of 2008 concerning the Compilation of Sharia Economic Law

Internet: 
[1] Damanhuri Fattah, "Teori Keadilan Menurut John Rawls", terdapat dalam http://ejournal.radenintan.ac.id/index.php/TAPIs/article/view/1589 Diakses terakhir tanggal 12 September 2018

[2] Denda dalam Islam, dalam http://www.google.co.id/search [home pageonline]: internet Denda dalam islam, dalam http://www.google.co.id/search [home pageonline]: internet

[3] Force Majeur yang berarti "kekuatan yang lebih besar" adalah suatu kejadian yang terjadi di luar kemampuan manusia \& tidak dapat dihindarkan sehingga suatu kegiatan tidak dapat dilaksanakan atau tidak dapat dilaksanakan sebagaimana mestinya. Sumber: https://id.m. wikipedia.org/wiki/keadaan_kahar diakses pada tanggal 2 Maret 2021

[4] Totok Wahyu Abadi, "Aksiologi: Antara Etika, Moral, \& Estetika," KANAL: Jurnal Ilmu Komunikasi 4, no. 2 (March 3, 2016): p. 196, accessed October 15, 2020, http://ojs.umsida.ac.id/index.php/kanal/article/view/1452 